تأثير ادغام بقاياى گندم در خاك بر ويزگگىهاى فيزيولوزيك و عملكرد كنسروى ذرت شيرين تحت شرايط تنش آبى

اعظم معتضديان'، سيد عبدالرضا كاظمينى ^"و محمد جعفر بحرانى"

(تاريخ دريافت:

جكيده

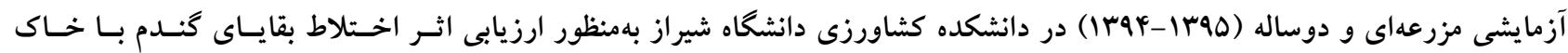

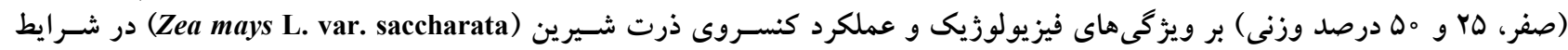

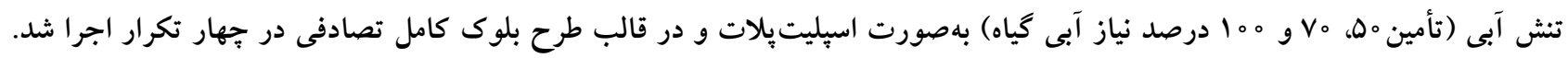

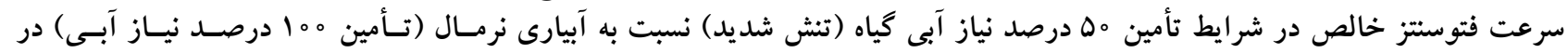

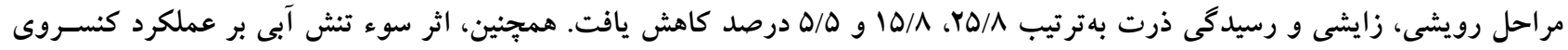

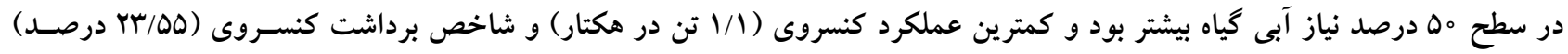

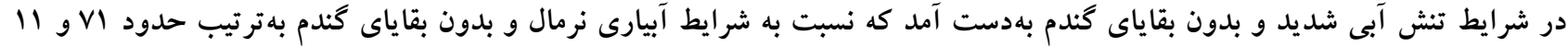

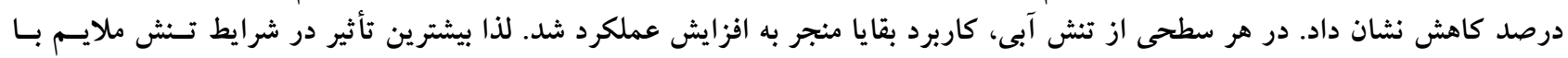

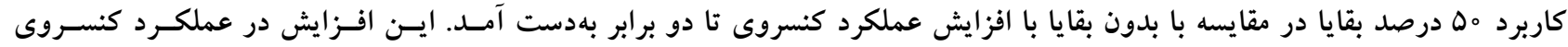

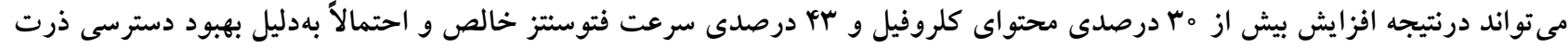

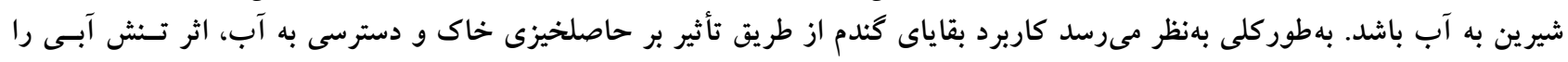

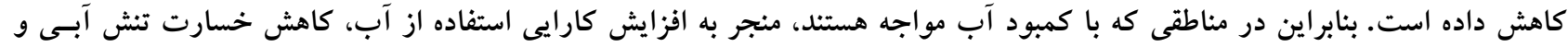

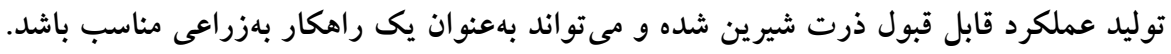

وازمهاى كليدى: تنش رطوبتى، فتوسنتز، محتواى كلروفيل

ا، r و r. بهترتيب دانشجوى كارشناسى ارشد، دانشيار و استاد، بخش زراعت و اصلاح نباتات، دانشكده كثاورزى، دانشكاه شيراز *: مسئول مكاتبات: بِت الكترونيكى: akazemeini@shirazu.ac.ir 
نيامدن خسارت شديد به كياه در اثر تسنش آبسى، در مقـدار آب

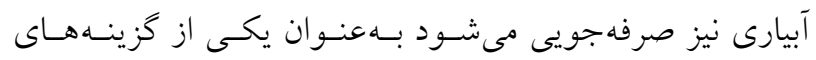

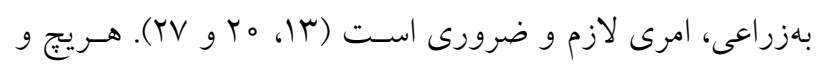

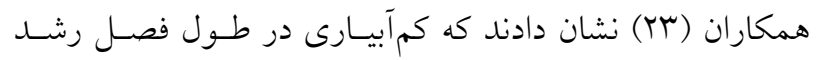

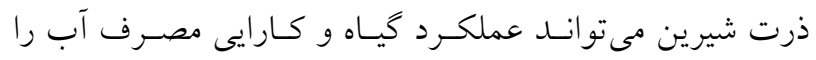

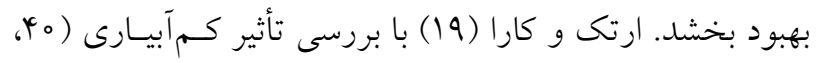

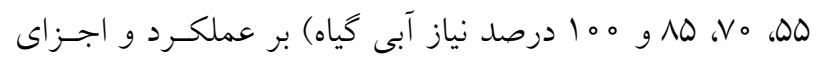

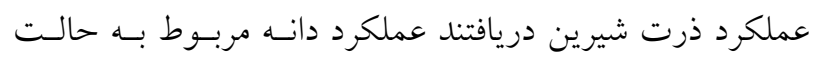

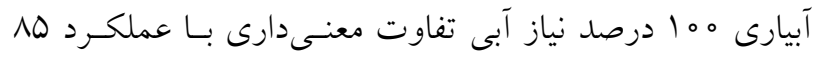

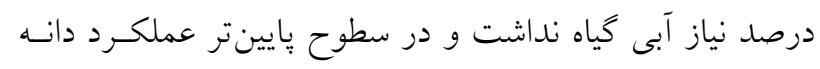
بلبطور معنى دارى كاهش نشان داد.

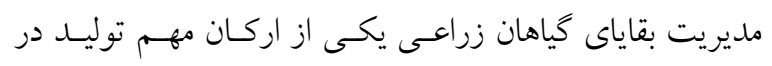

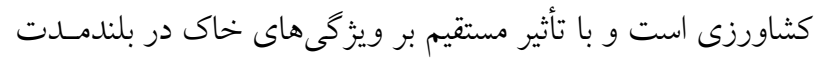

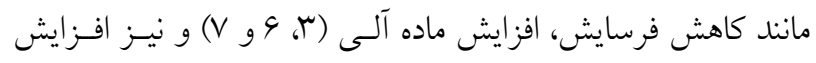

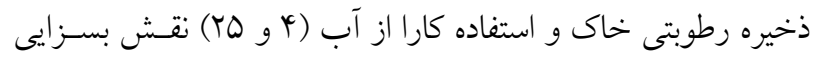

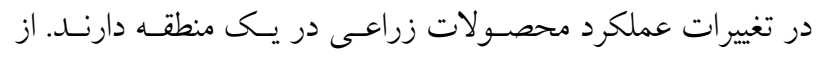

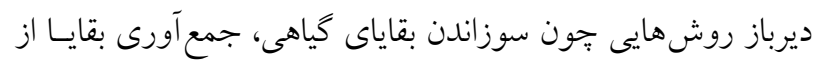

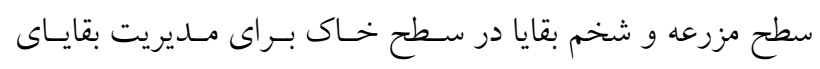

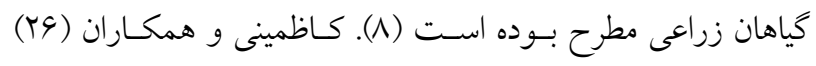

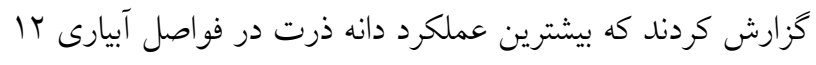

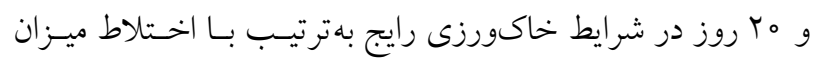

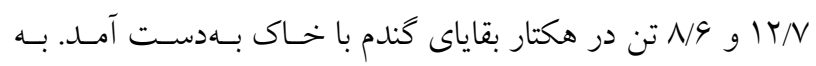
عبارتى حفظ و نخهدارى سطوح بايينتــر بقايساى كنـدم در شـرايط

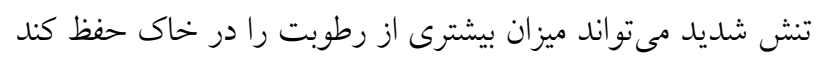

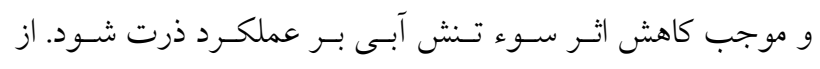

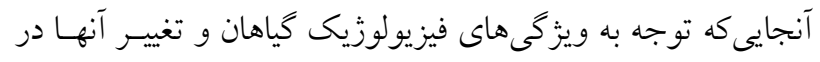

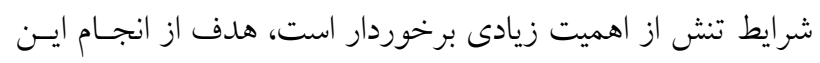

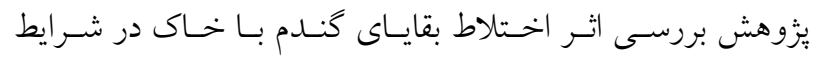

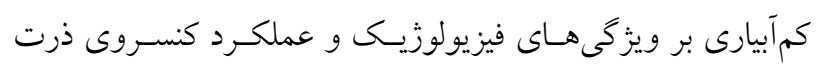
شيرين در منطقه باجكاه بود.

\section{مواد و روشها} بهمنظور بررسى اثر اختلاط بقاياى كندم با خاك و كـــآبيـارى بــر

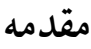

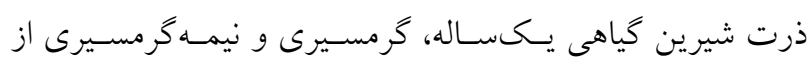

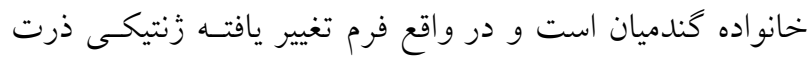

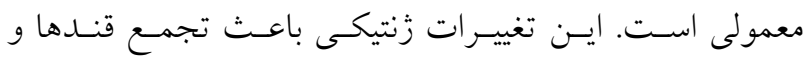

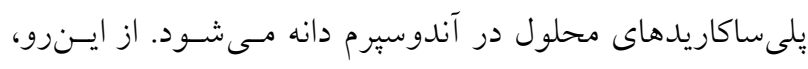

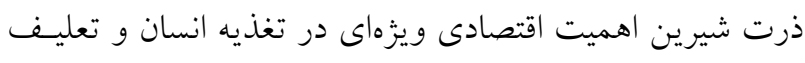

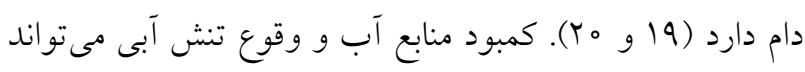

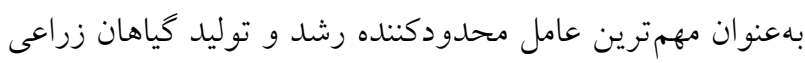

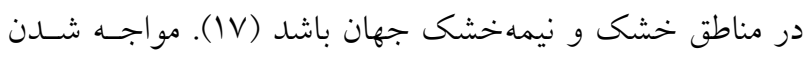

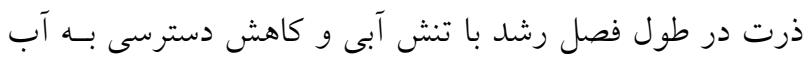

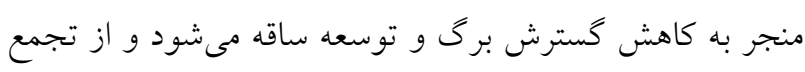

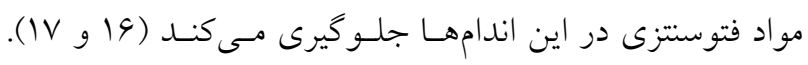

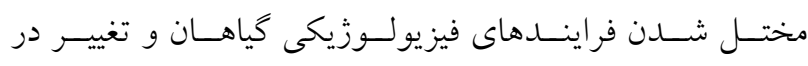

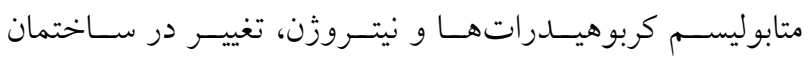

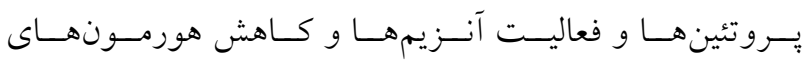

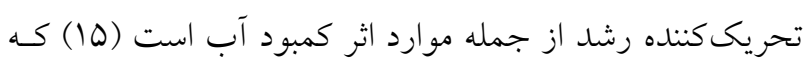

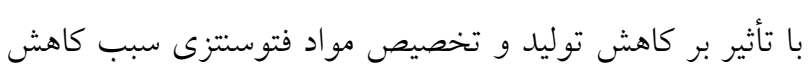

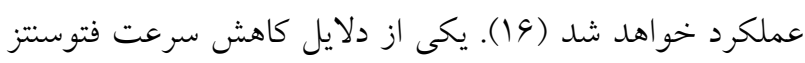
خالص، تشكيل كونههـاى فعـال اكسيزن (راديكـالهـاى آزاد)

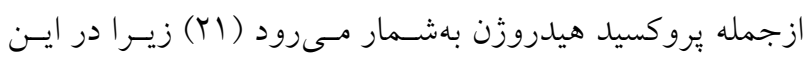

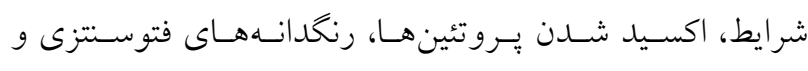
اسيدهاى نو كلوئيك رخ داده و كلروز و نكروز شدن بـن بافت كيـاه

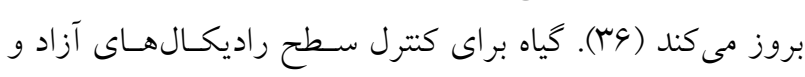

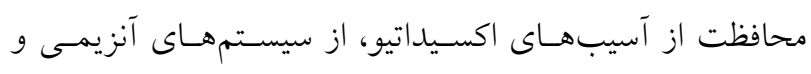

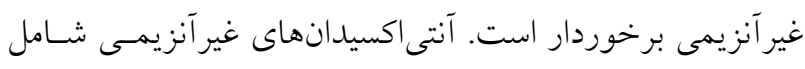

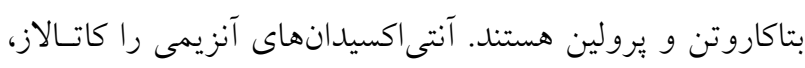

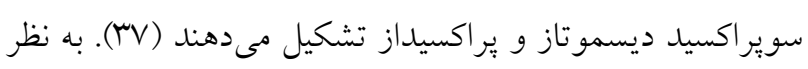

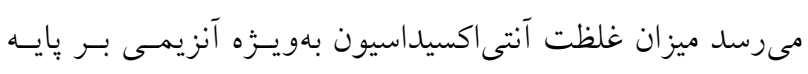

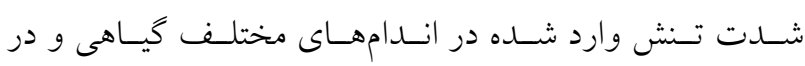

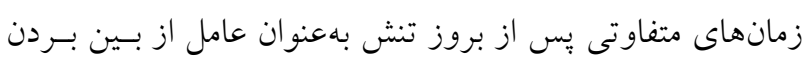

كونههاى فعال اكسيزن عمل مى كنند (TY)

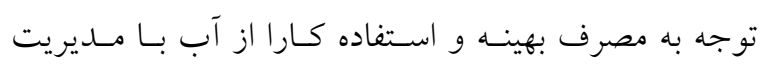

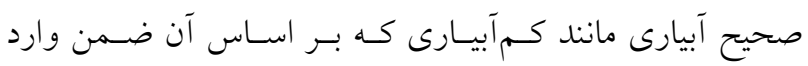


تأثير ادغام بقاياى كندم در خاك بر ويزٔى هاى فيزيولوزيك و....
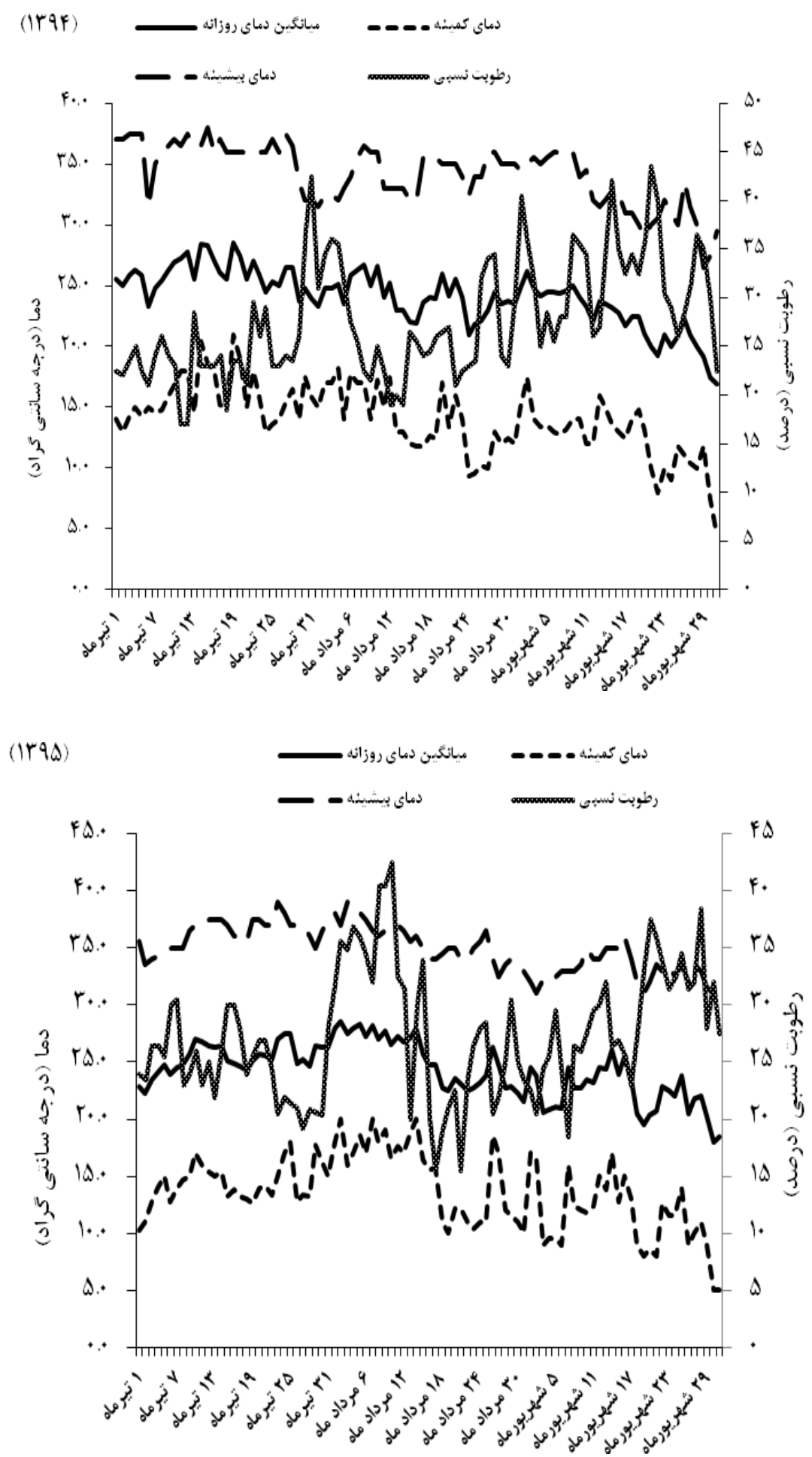

شكل ا. نوسانات دمايى و رطوبت نسبى روزانه در منطقه باجگاه در طول فصل رشد گياه زراعى ذرت شيرين

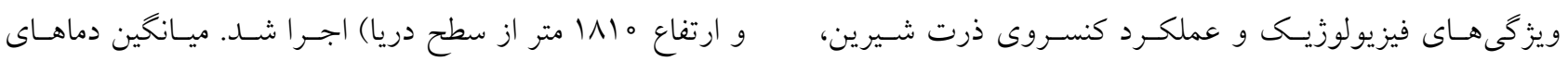

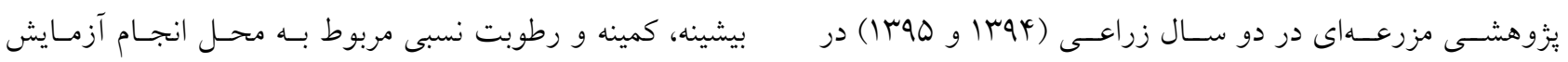

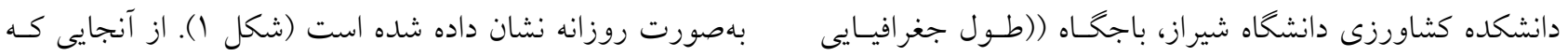

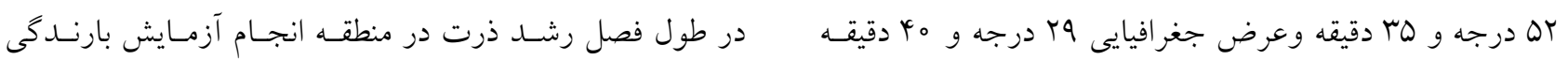

kr 
تشعشـع نـور خورشـيد صسورت يـذيرفت (تنهـا در سـال دوم

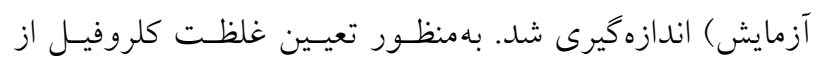
روش آرنـون (ه)، مقــدار يــرولين از روش بيـتس (9) و ميـزان

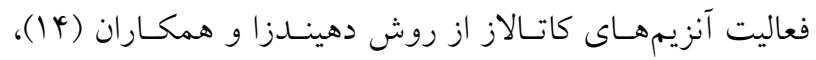
يراكســيداز از روش جهـانس و مــاهلى (Y) و ســوير اكسـيد

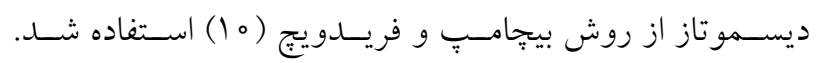

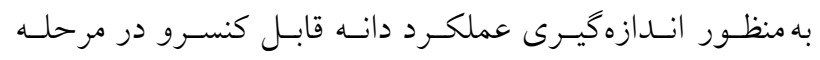
رسيدگى اقتصادى ذرت شيرين در اوايل مرحلـه خميـرى (V0ه9 درصد رطوبت) از دو خط وسط هر كرت (يك متر طولى از هر خط) با حذف حاشيه، از ناحيه مركزى هر كـرت بـا دسـت بهطور كامل برداشت شد و دانه بلالهـاى تـازه برداشت شده با

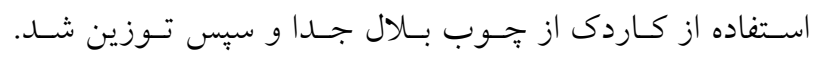
شاخص عملكرد كنسـروى از تقسـيم وزن دانــهـ كنسـروى بـر عملكرد تر بلال با يوشش محاسبه شد. از تقسيم عملكرد بـلال با يوشش بر مقدار آب مصرفى، كارايى مصرف آب محاسبه شد

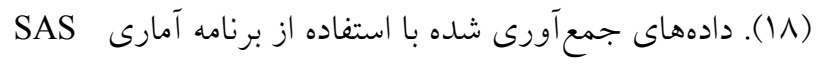
9.1 مورد تجزيهو تحليل آمارى قرار كرفت و ميانخينهـا توسـط آزمون دانكن در سطح ينج درصد مقايسه شدند. بـراى بررسىى همخن بودن واريانس ها از آزمون بارتلت نيز استفاده شد (بم).

\section{نتايج}

صفات بيوشيميايى نتايج تجزيه مركب دادههـا نشـان داد كـه اتشر سـال و همجنــين برهم كنش سال با تنش آبى و سطوح بقاياى كندم براى هيج يك

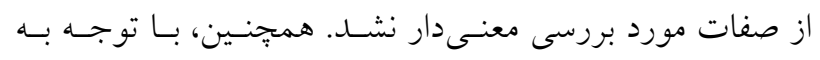

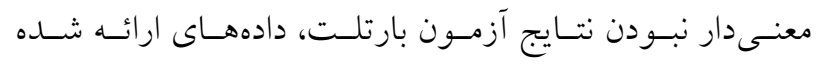
بهصورت ميانگين دو سال ارائه شد (جدول (1). ميزان كلروفيـل در برگ ذرت شيرين تحت تأثير سطوح تنش آبى در سطح يك درصد و بقاياى كندم و برهمكــش آنهـا در سـطح يـنج درصــ

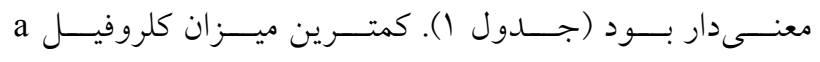

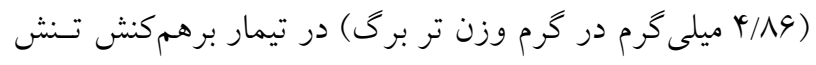

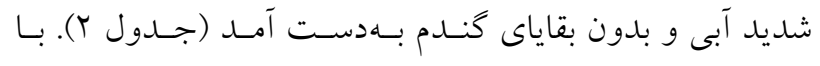
كاهش شدت تنش آبى اثر سوء تنش بر كلروفيل a كمتـر شــده

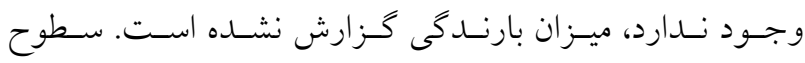

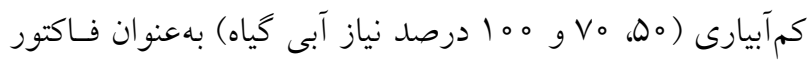
اصلى و فـاكتور بقايـاى گنـدم (صـفر، ه广 و •ه درصـد وزنسى

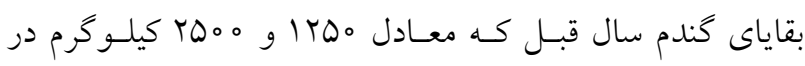
هكتار، رقم بيشتاز بوده است) در كرتهـاى فرعسى بـهــورت اسيليت يلات و در قالب طرح بلـوى كامـل تصـادفى در جهـار تكرار اجرا شد. بافت خاك مزرعه از نـوع سـيلتىرسسى بـود و

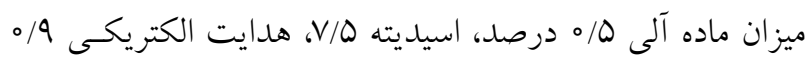
دسىزيمنس بر متر و نيتروزن كل ب ا/ه درصد در عمق صفر تـا 。 سانتى مترى خاك محاسبه شد. نياز آبسى گيـاه بـا اسـتفاده از فرمول ينمن مانتيت اصلاح شده كه بر اساس متغيرهاى تبخير و تعرق گياه مرجع، تابش خالص در سطح يوشش گياهى، متوسط

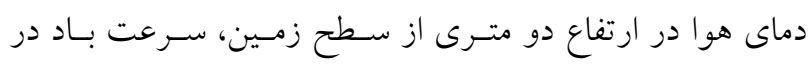
ارتفاع دو مترى از سطح زمين، كمبود فشار بخار آب در ارتفـاع دو مترى، شيب منحنى فشار بخار، ضـريب رطـوبتى و شـارش كرما به درون خاك محاسبه شد (هץ). بذر هيبريد ذرت شسيرين ايرانى (متوسطرس، داراى قند بالا، بلال خوشفرم و كشـيده بـاـ

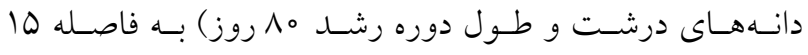
سانتى متر روى يشتههايى به فاصله VD سـانتى متـر از يكـديخر و به طول جهار متر كاشت شد. هر كرت فرعى شامل جهـار خـط كاشت بود كه توسط دو خـط نكاشـت از كـرت بعـدى جــا و براى اطمينان از اعمال تنش آبى، بين كرتهــاى اصـلى دو متـر فاصله درنظر كرفته شد. روش آبيارى قطـرهاى و بــا اسـتفاده از

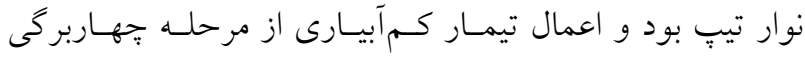
شروع شد. آبيارى در همه كرتها با فواصل جهار روزه و ميزان

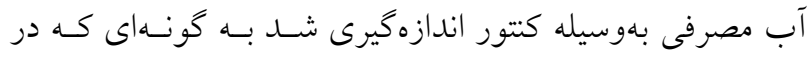
شرايط آبيارى نرمال (ه ما درصد نيـاز آبس) و در طـول فصـل

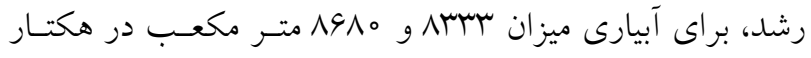
بهترتيب در سال عqها و هوسا آب مورد استفاده قـرار كرفتـ. سرعت فتوسنتز خالص (A)، هدايت روزنهاى (gs) و دى (As) بكسيد كربن زيــر روزنـهاى (Ci) بـا اسـتفاده از دسـتخاه LCI شـركت

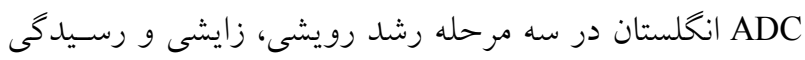

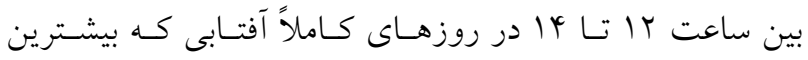




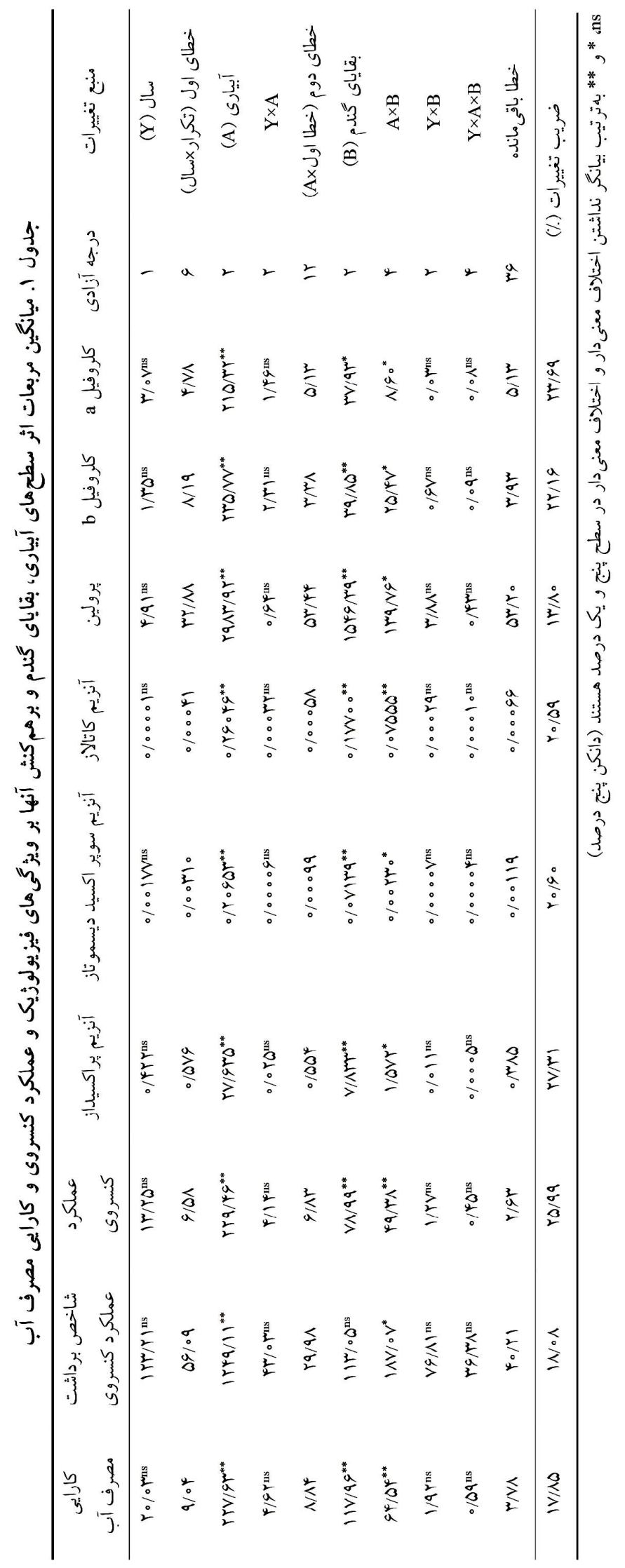




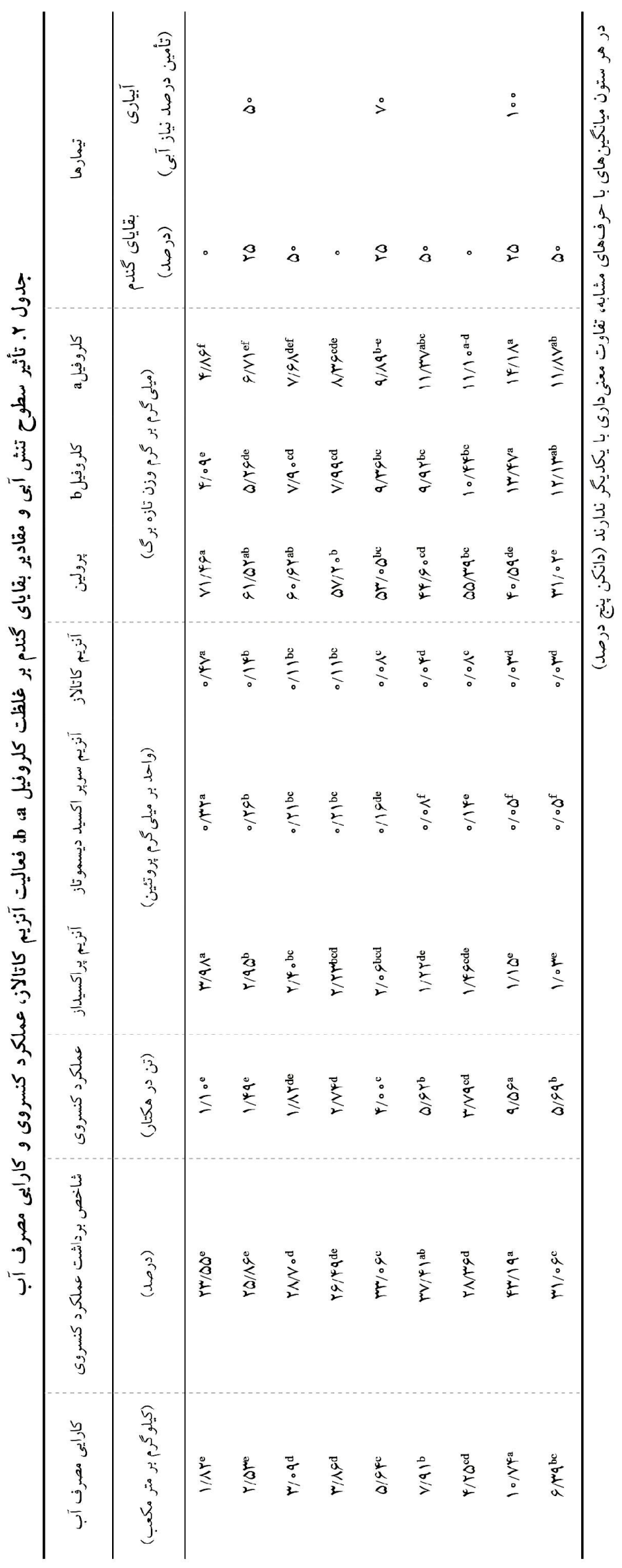


آنزيمهاى آنتى اكسيدان و محتواى اسـيدآمينه هـرولين در سـطح

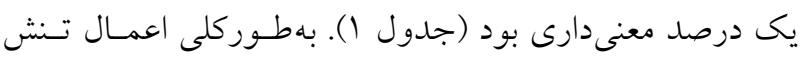

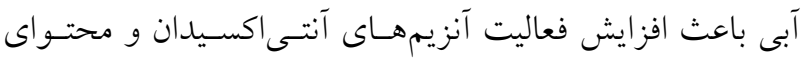

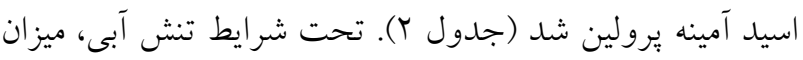

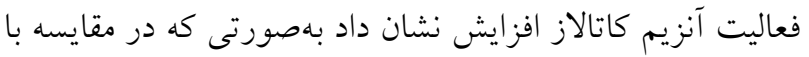
آبيارى نرمال، اعمال تنش ملايم باعث افزايش فعاليت اين آنزيم

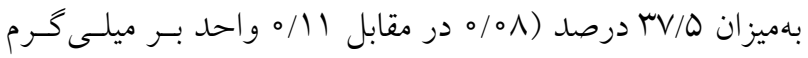

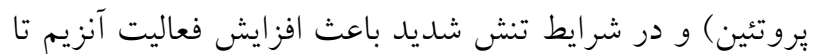

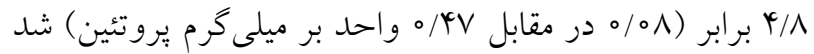

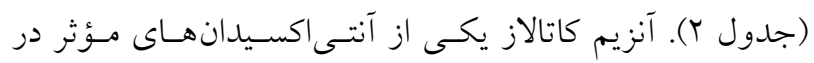

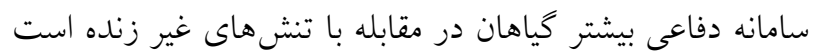

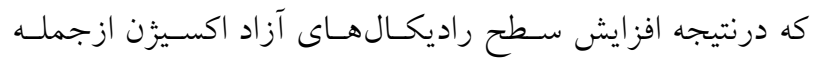

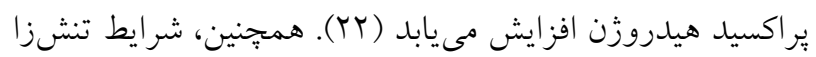

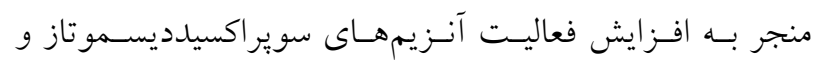

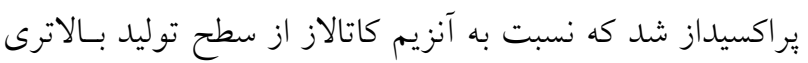
برخوردار بود كه خود سازوكارى حفاظتى كيـاه در برابـر توليـــ

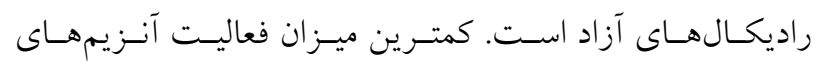

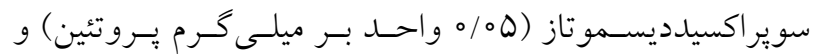

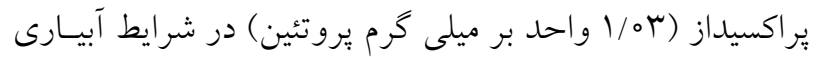

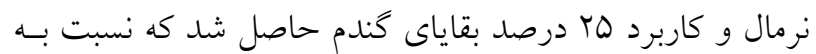
سطح 00 درصد بقاياى گندم تفاوت معنى دارى نداشت (جدول Y). ترولين نيز يكى از اسموليتهاى مؤثر در مقاومت به شرايط

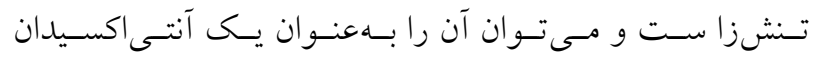

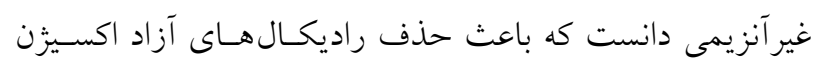

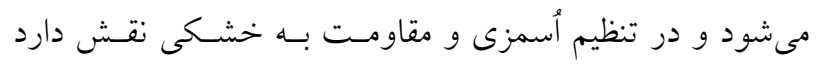

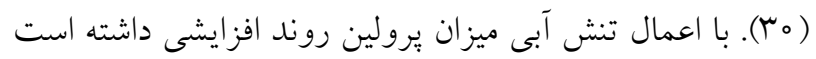

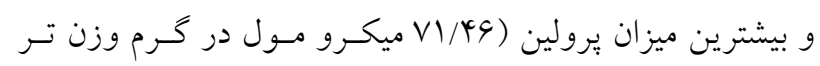

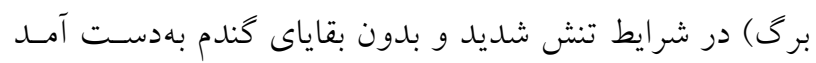

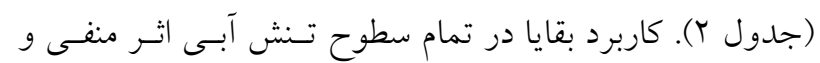

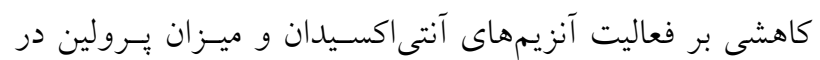

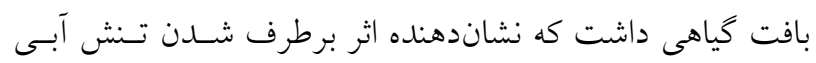

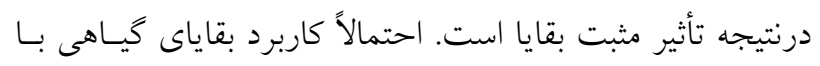

است، بهصورتى كه در شرايط V0 درصد نياز آبى گيساه (تسنش

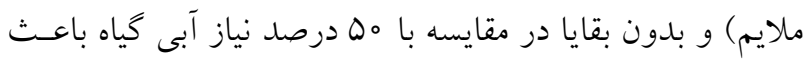

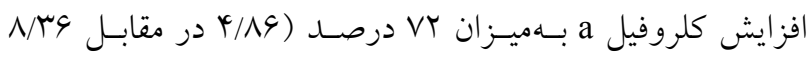
ميلى گرم در گرم وزن تر برى) شده است و در شـرايط آبيـارى

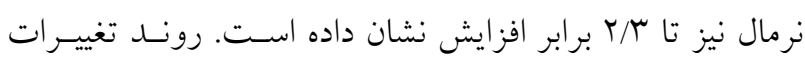

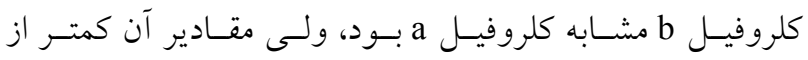

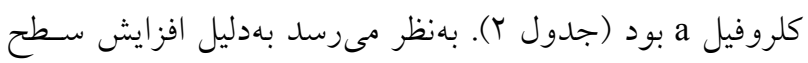

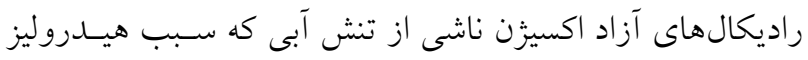

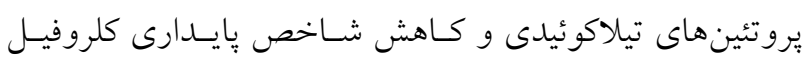

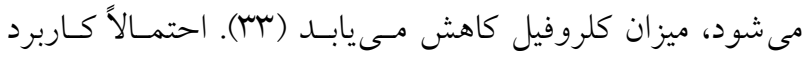

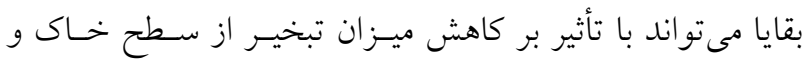

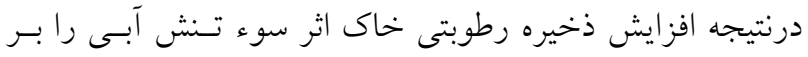

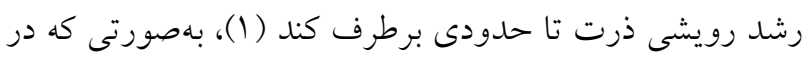

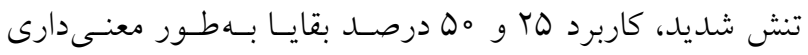

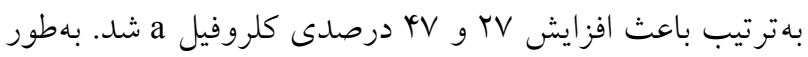

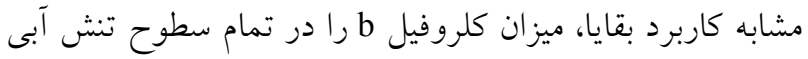

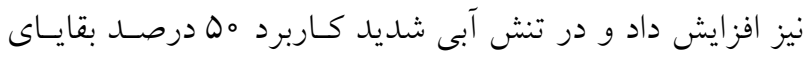

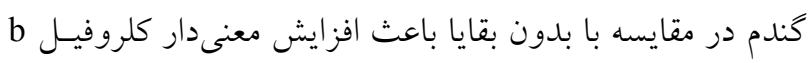

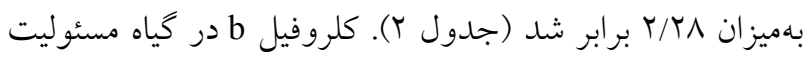

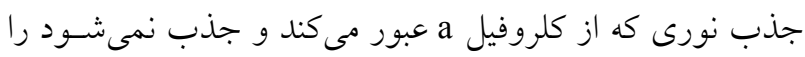
بر عهده دارد و بهعبارتى كلروفيل b در كنار كلروفيل a رانـدمان جذب تابش خورشيدى را افزايش مىدهد كـه منجـر بـهـ بهبـود ظرفيت فتوسنتى كياه مىشود. رابطه رگرسيونى ميان كلروفيـل

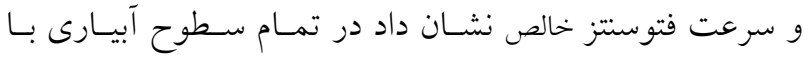

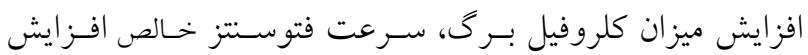

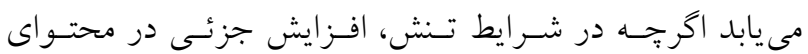

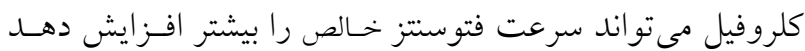

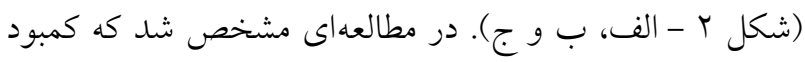

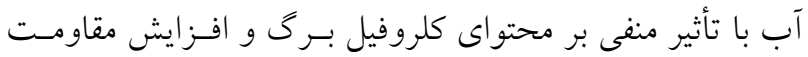

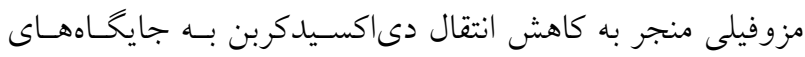

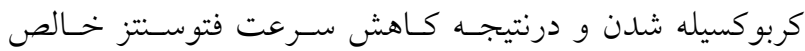

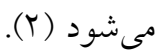
نتايج تجزيه واريانس نشـان داد اثـر تسنش آبـى بــر فعاليـت 

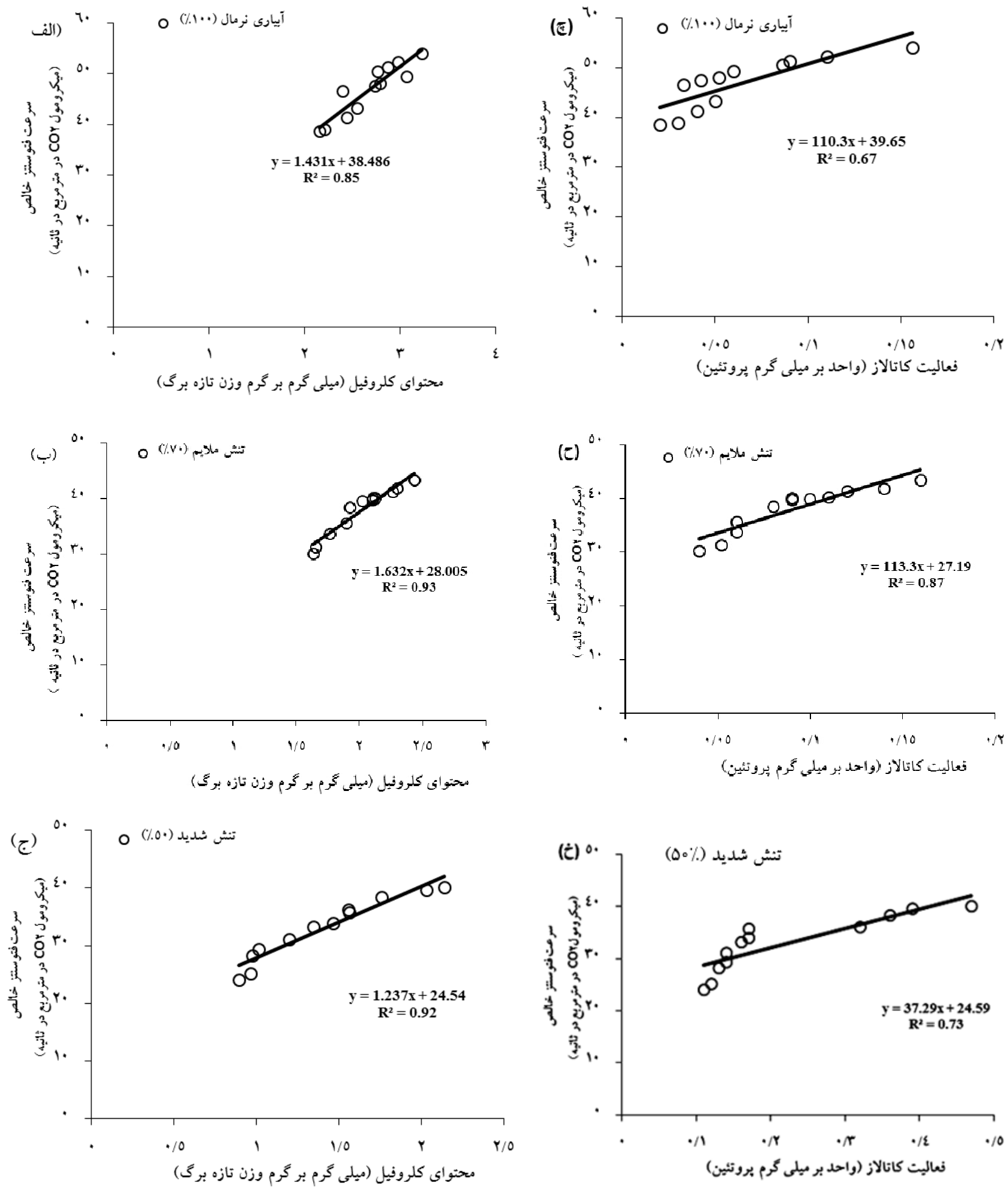

شكل r. رابطه ركرسيونى ميان سرعت فتوسنت خالص با محتواى كلروفيل برگ ((الف)، (ب) و (ج)) و فعاليت آنزيم كاتالاز ((ج)، (ح) و

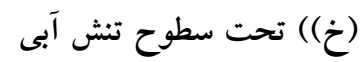


و كمترين عملكـرد كنسـروى (1/1 تسن در هكتـار) و شـاخص

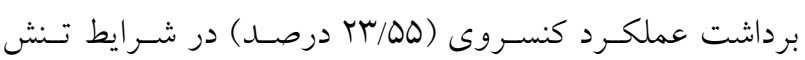
شديد و بدون بقاياى گندم بهدست آمد كـه نسـبت بـه شـرايط

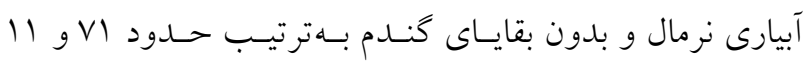

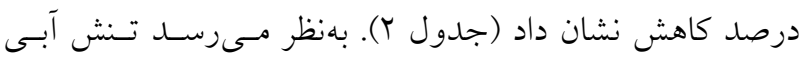

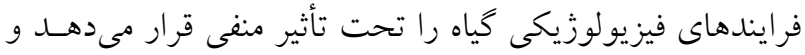

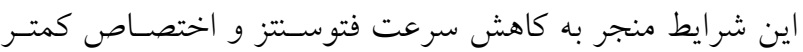
مواد يرورده به اندامهاى زايشى ذرت مىشود. بهطسوركلى تـأثير

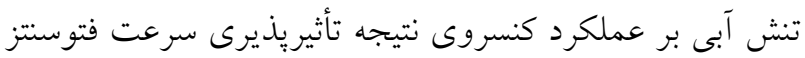

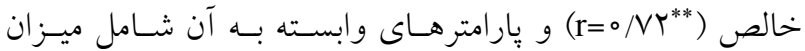

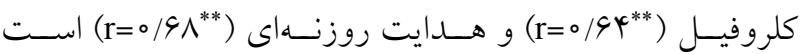

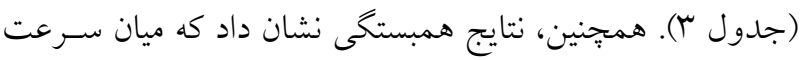

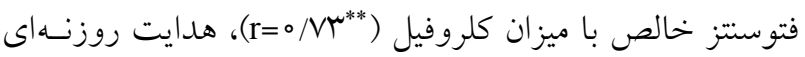

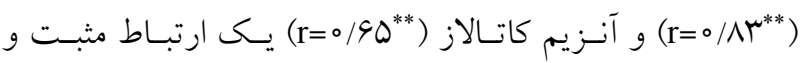

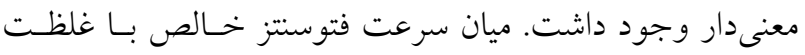

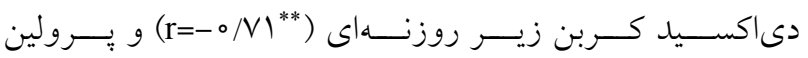

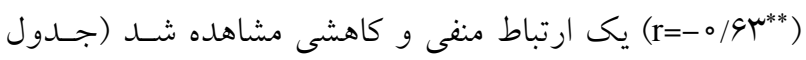

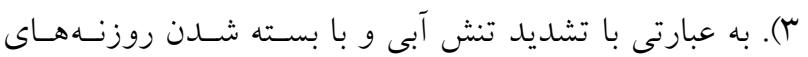

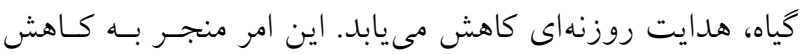

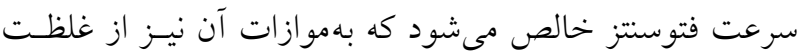
كلروفيل در بركها كاسته مىشود ( آr). تنش آبى هرجند سبب كاهش عملكرد كنسروى ذرت شيرين شــ، ولـى كـاربرد بقايـا توانست تا حلدودى اثر سوء تسنش را برطـرف و كـاهش دهـد،

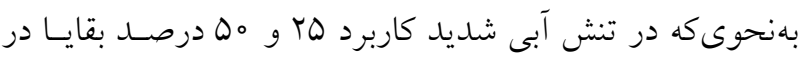

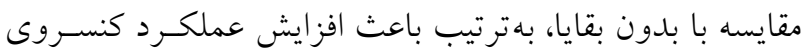

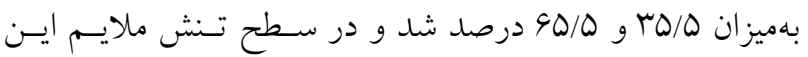
افزايش بهترتيب بهميزان و ب درصد و دو برابر بوده است كه اين

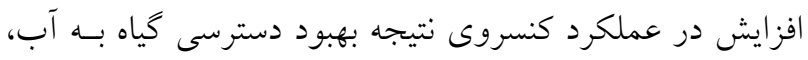

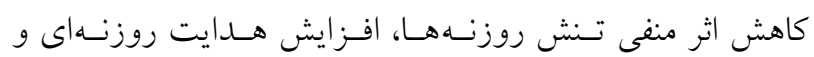

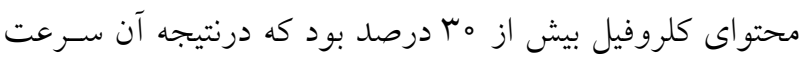
فتوسنتز خالص نيز بهميزان بها درصد افزايش يافت (جدول Y).

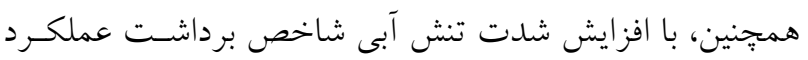

بهبود خواص فيزيكى و شيميايى خـاك و كـاهش تلفـات آب از

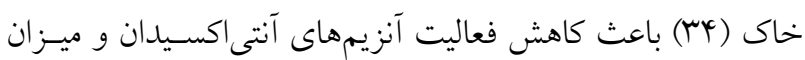
يرولين مىشود، بهصورتى كه تحت شرايط تنش آبى شديد ميـزان

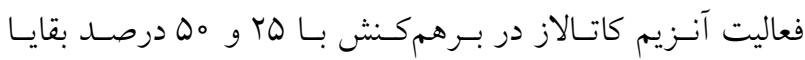
بهترتيب بهميزان Vo و V9 درصد كاهش يافـت. در شـرايط بـدون

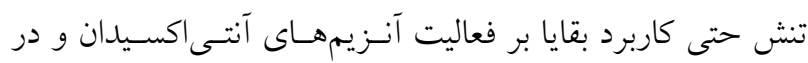

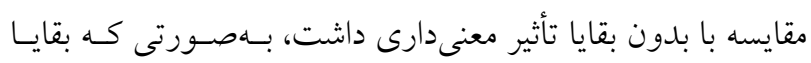

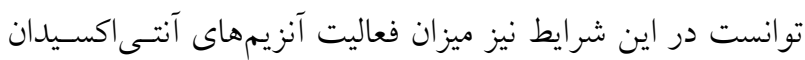

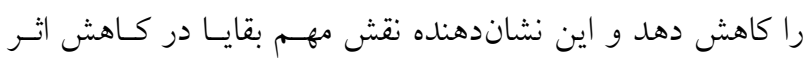

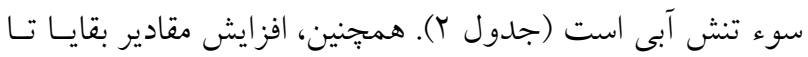

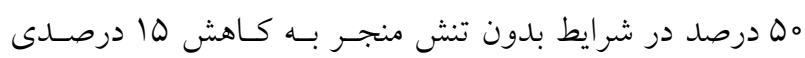

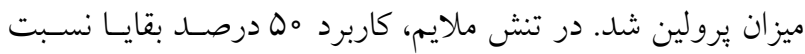

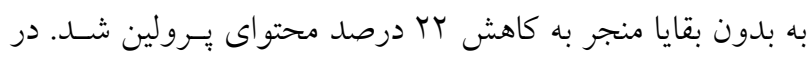

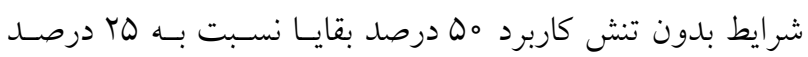

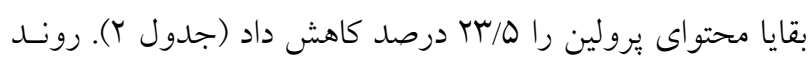

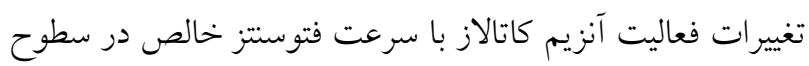

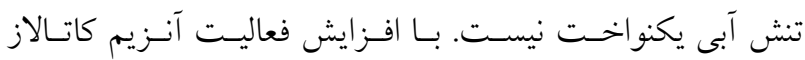

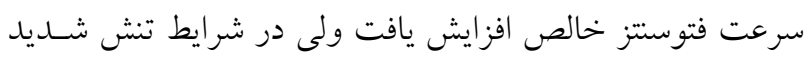

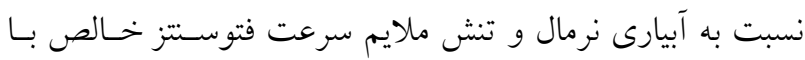

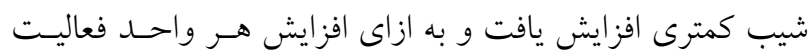

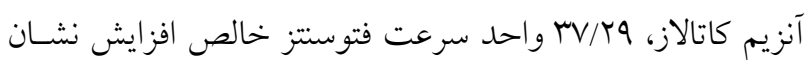

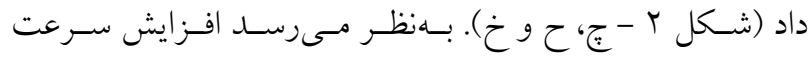

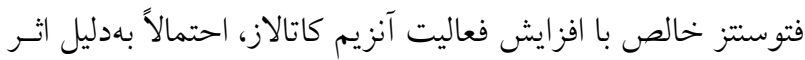

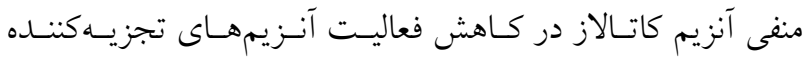
يروتئين و بهبود فعاليت آنزيم روبيسكو است (11).

\section{عملكرد كنسروى ذرت شيرين}

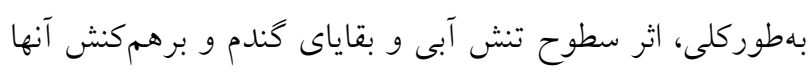

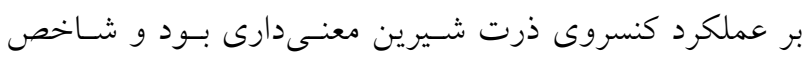

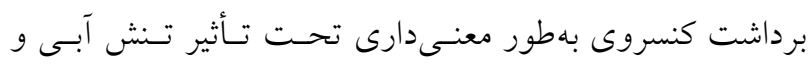

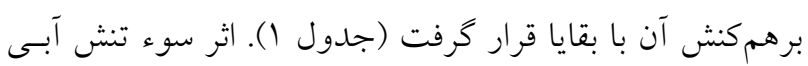

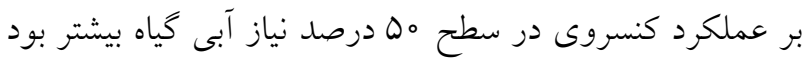




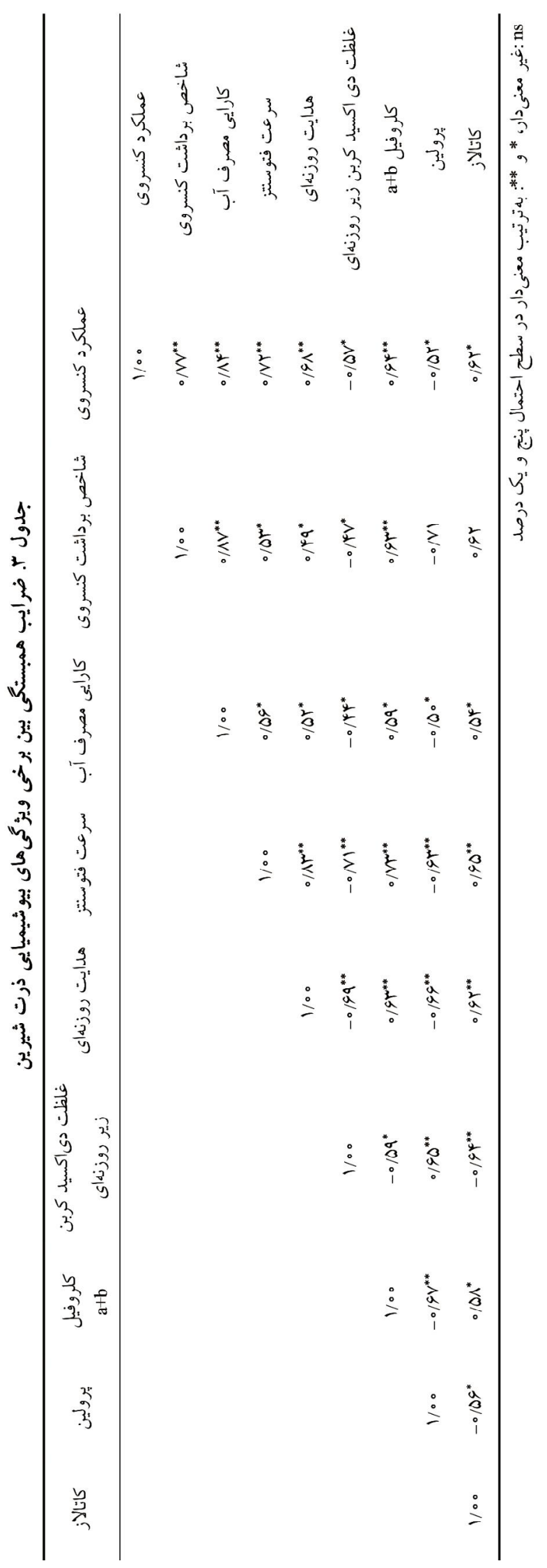




\section{فتوسنتز و ويزّكى هاى وابسته به آن}

نتايج تجزيه واريانس نشـان داد كـه در مرحلـه رويشسى فقـط

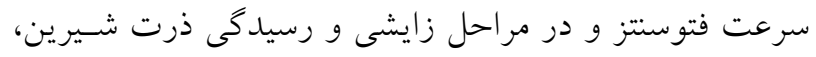

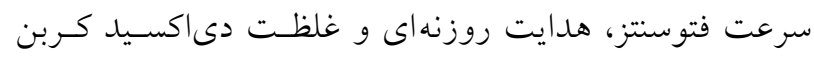

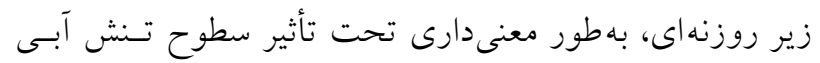

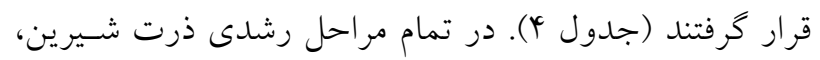

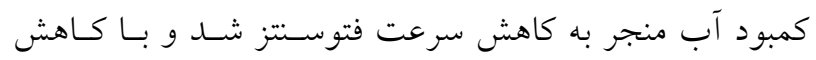

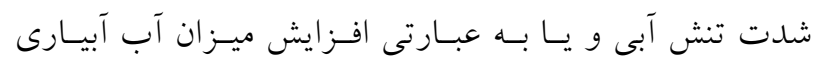

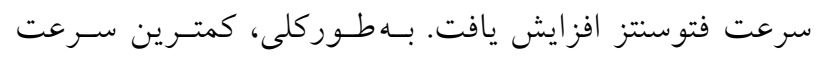

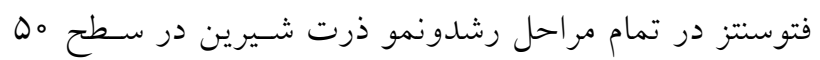

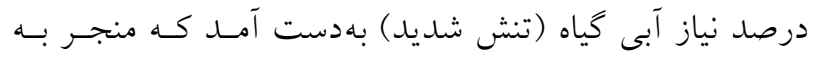

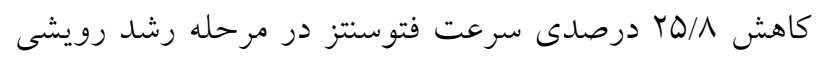

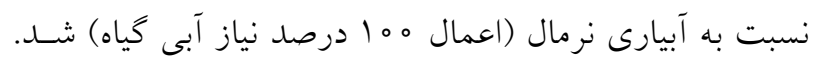

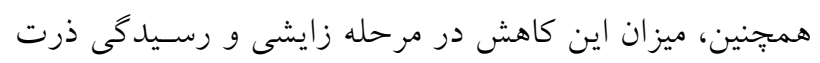

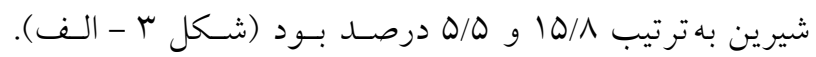

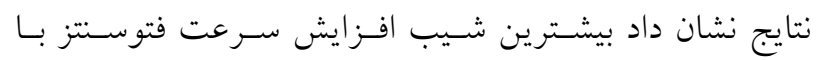

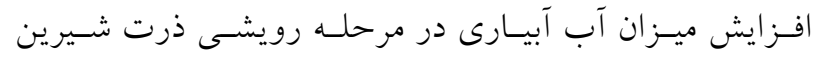

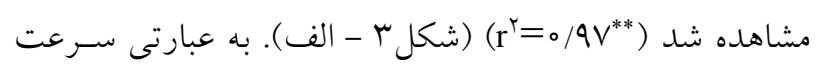

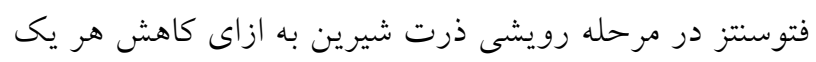

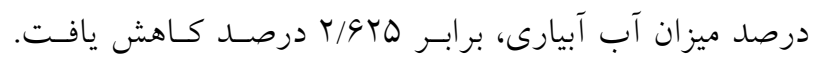

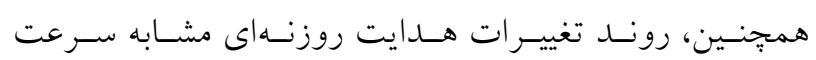

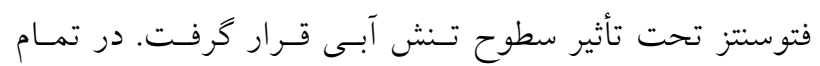

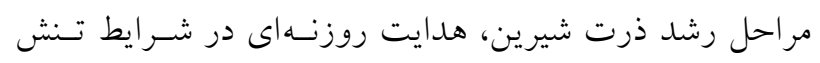

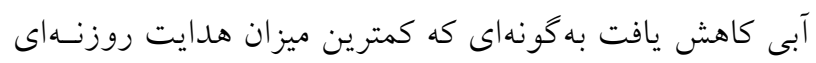

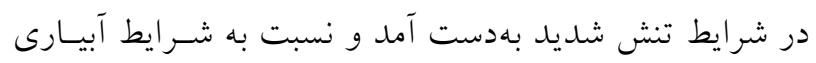

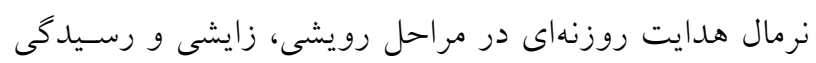

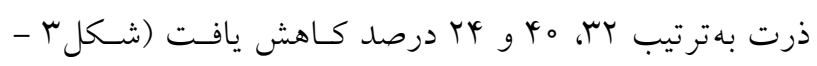

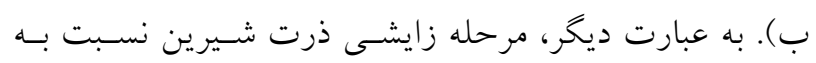

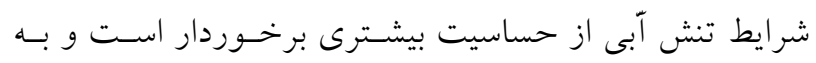

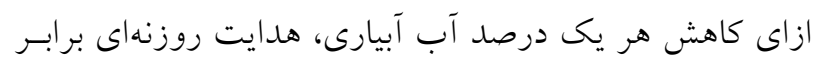

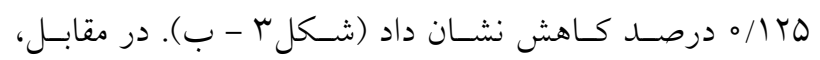
غلظت دىاكسيد كربن زير روزنهاى در شرايط آبيـارى نرمـال

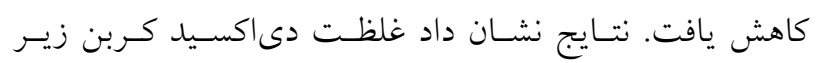

كنسروى ذرت كاهش يافـت بـه كونـهاى كـه كمتـرين شـاخص

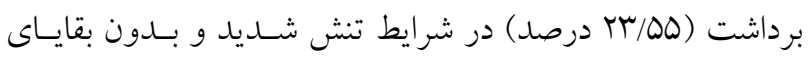

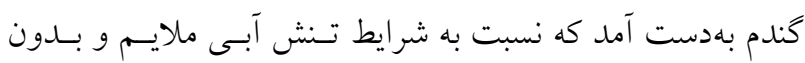

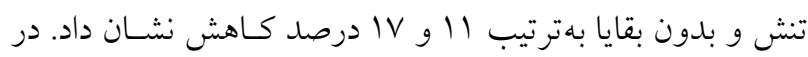

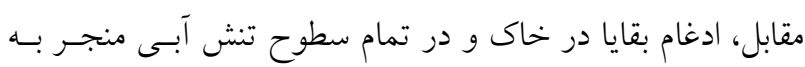

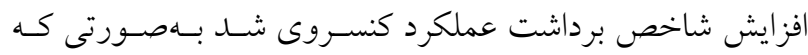
شاخص برداشت در شرايط تنش شديد با كاربرد مه درصد بقايـا

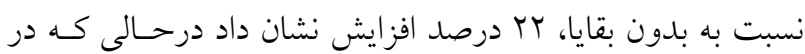

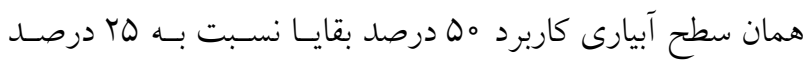
بقايا تنها لا درصد شاخص برداشت را افزايش داد (جدول ب).

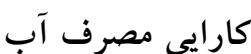

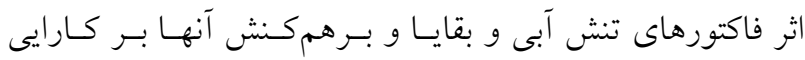

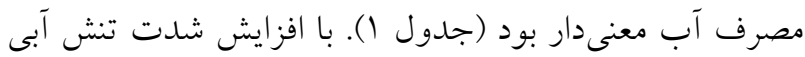

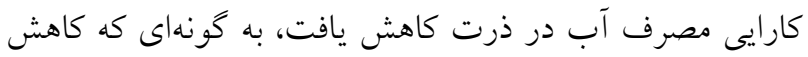

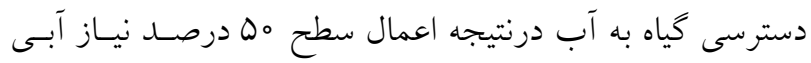

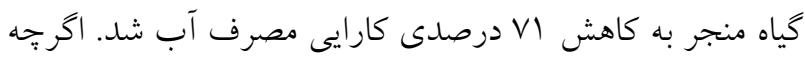

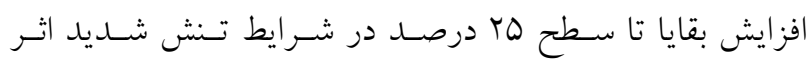

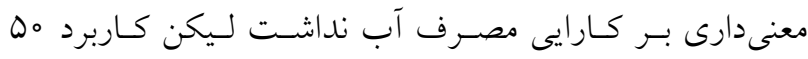

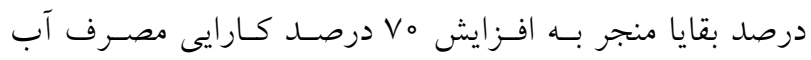

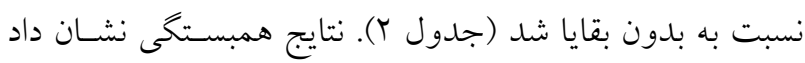

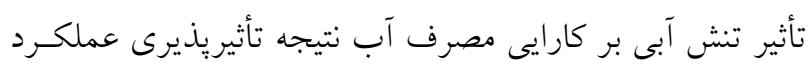

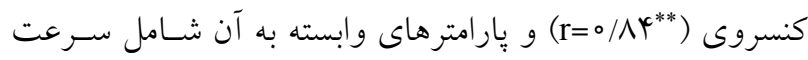

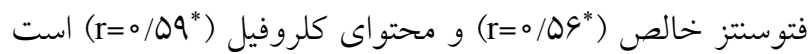

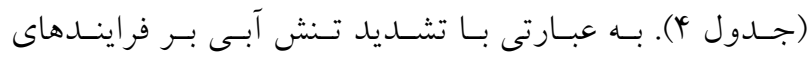

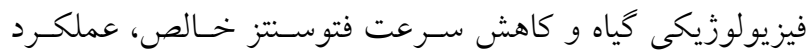
كنسروى نيز كاهش مىيابد كه درنهايت منجر به كاهش كـاريى ونسي

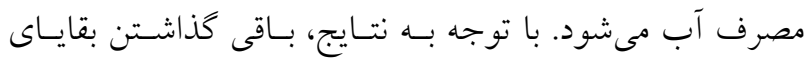

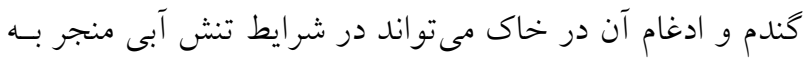

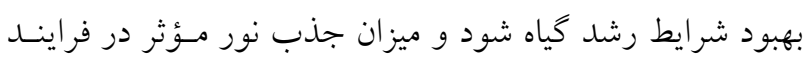

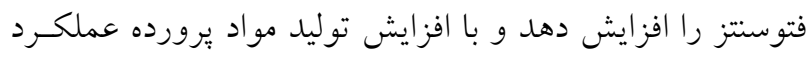

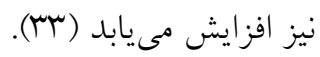




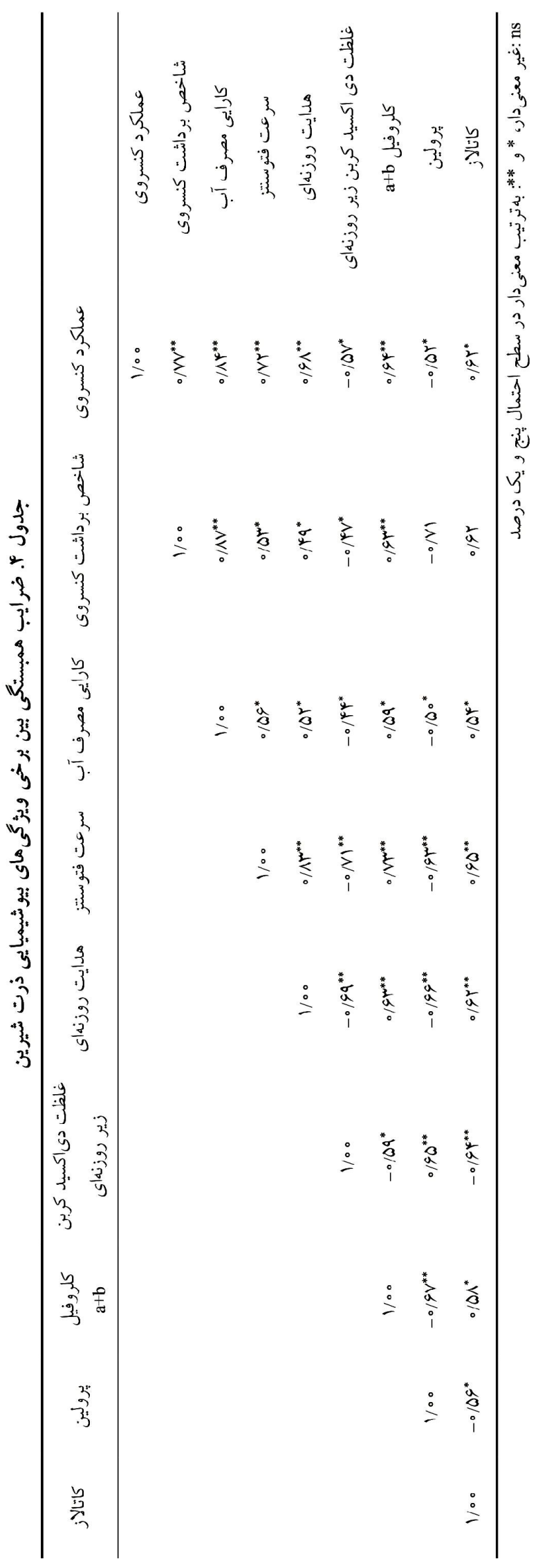



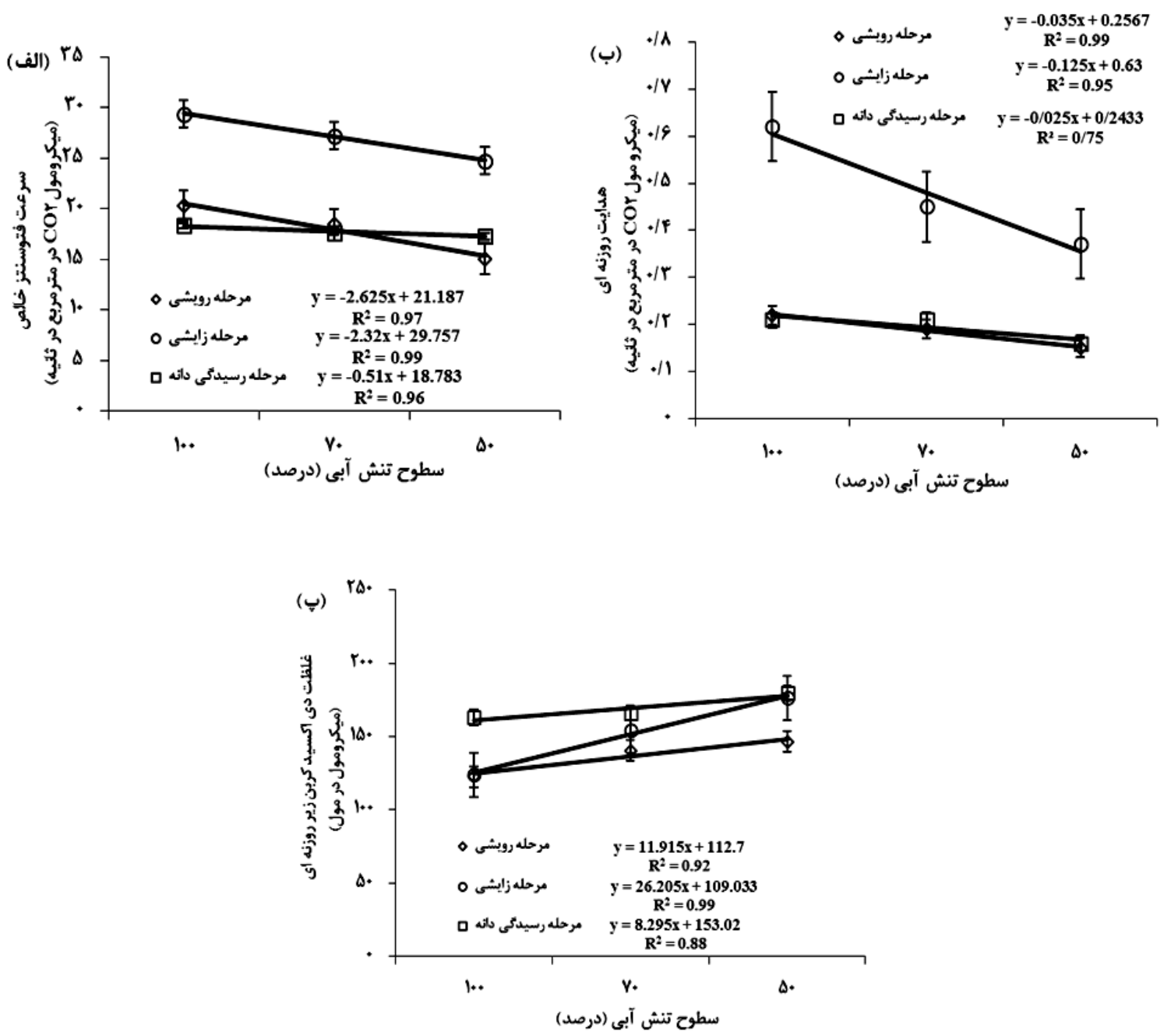

شكل r. اثر سطوح تنش آبى بر الف) سرعت فتوسنتز خالص، ب) هدايت روزنهاى و ج) غلظت دىاكسيد كربن زير روزنهاى. ميلههاى با آل هميوشانى مشابه بر اساس خطاى استاندارد (ISE) تفاوت معنى دارى ندارند.

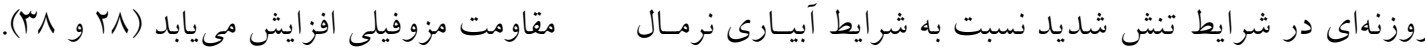

\section{نتيجه كيرى}

نتايج نشان داد تنش آبى با اثر سوء و منفى بـر كـاهش وب درصــى

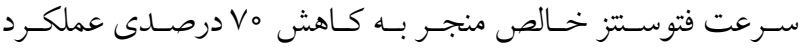

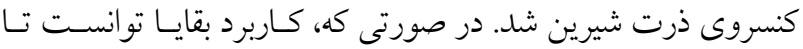
حدودى اثر سوء تنش را برطرف و كاهش دهل، بهنحوى كه در تـش

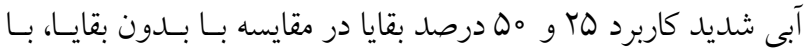
افزايش محتواى كلروفيل تـا بــش از مبادرصــ و سـرعت فتوسـتز

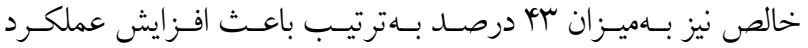
كنسروى بهميزان ه/ه/ه و 90/ه درصد شد. همجينين، در شرايط تـنش در مراحل رويشى، زايشى و رسيدگى ذرت بهترتيـب 19، بأو

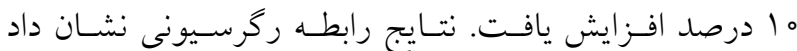
غلظت دىاكسيد كربن زير روزنسهاى بـه ازاى كـاهش هـريــ درصد آب آبيارى در مرحله زايشى ذرت شيرين با يـى شسيب

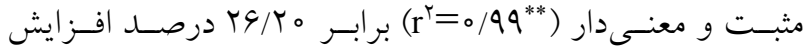

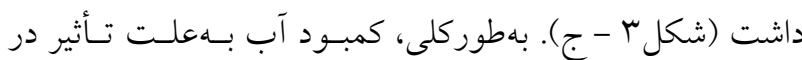
بسته شدن روزنهها و درنتيجه كاهش دسترسى گياه به دىاكسيد كربن در مزوفيل، باعث كاهش فتوستز كياه مىشود (Y9). بسته

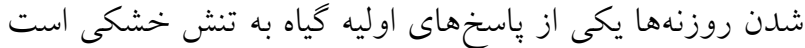
و به موازات كاهش در فتوسنتز، هدايت روزنهاى گياه كـاهش و 


$$
\begin{aligned}
& \text { مصرف آب نسبت به كاربرد ه T درصد بقايـا شـــ. بـهنظـر مسىرســ } \\
& \text { ملايم كاربرد هT و مه درصد بقايا در مقايسه با بدون بقايا، بـهترتيـب } \\
& \text { كاربرد •ه درصد بقاياى كندم با تـأثير بـر بهبـود وضـعيت آب قابـل } \\
& \text { باعث افزايش عملكرد كنسروى بهميـزان وه درصــ و دو برابـر شـد. } \\
& \text { دسترس تحت شرايط تنش ملايم، يتانسيل توليـد عملكـــد كنسـروى }
\end{aligned}
$$

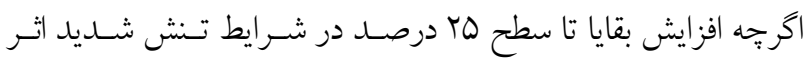

$$
\begin{aligned}
& \text { دانه ذرت شيرين را در مقايسه با شرايط آبيارى نرمال در سـطح قابـل } \\
& \text { معنى دارى بر كارايى مصرف آب نداشـت لـيكن كـاربرد مه درصــ } \\
& \text { قبولى حفظ مى كند. } \\
& \text { بقايا در شرايط تنش ملايــم منجـر بــه افـزايش مب درصــى كـارايى }
\end{aligned}
$$

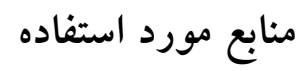

1. Abdullah, A. S. 2014. Minimum tillage and residue management increase soil water content, soil organic matter and canola seed yield and seed oil content in the semiarid areas of Northern Iraq. Soil and Tillage Research 144: 150-155.

2. Ahmadi, A. and D. A. Baker. 2001. The effect of water stress on the activities of key regulatory enzymes of the sucrose to starch pathway in wheat. Plant Growth Regulation 35: 81-91.

3. Alijani, K., M. J. Bahrani and S. A. Kazemeini. 2011. Effects of tillage methods and rates of corn residues on wheat growth, yield and yield components. Iranian Field Crops Research 9: 486-493. (In Farsi).

4. Anderson, R. L. 2008. Residue management tactics for corn following spring wheat. Weed Technology 22: 177-181.

5. Arnon, A. N. 1967. Method of extraction of chlorophyll in the plants. Agronomy Journal 23: 112-121.

6. Bahrani, M. J. 1998. Management of crop residues in irrigated farming systems. In: Proceeding of the $5^{\text {th }}$ Congress of Crop Production and Plant Breeding, Karaj, Iran. pp. 26. (In Farsi).

7. Bahrani, M. J., M. Kheradnam, Y. Emam, H. Ghadiri and M. T. Assad. 2002. Effects of tillage methods on wheat yield and yield components in continuous wheat cropping. Experimental Agriculture 38: 389-395.

8. Bahrani, M. J., M. H. Raufat and H. Ghadiri. 2007. Influence of wheat residue management on irrigated corn grain production in a reduced tillage system. Soil and Tillage Research 94: 305-309.

9. Bates, L. S., R. P. Waldren and I. D. Teare. 1973. Rapid determination of free proline for water-stress studies. Plant and Soil 39: 205-207.

10. Beauchamp, C. and I. Fridovich. 1971. Superoxide dismutase: improved assays and an assay applicable to acrylamide gels. Analytical Biochemistry 44: 276-287.

11. Castrillo, M. and I. Turajillo. 1994. Ribulose-1, 5-biphosphate carboxylase activity and chlorophyll and protein content in two cultivars of French bean plants under water stress and re-watering. Photosynthetica 30: 175-181.

12. Chance, B. and A. C. Maehly. 1955. Assay of catalases and peroxidases. Methods in Enzymology 2: 764-775.

13. Debaeke, P. and A. Aboudrare. 2004. Adaptation of crop management to water-limited environments. European Journal of Agronomy 21: 433-446.

14. Dhindsa, R. S., P. Plumb-Dhindsa and T. A. Thorpe. 1981. Leaf senescence: correlated with increased levels of membrane permeability and lipid peroxidation, and decreased levels of superoxide dismutase and catalase. Journal of Experimental Botany 32: 93-101.

15. Di Marco, O. N., M. S. Aello and A. Chicatún. 2007. Effect of irrigation on corn plant dry matter yield, morphological components and ruminal degradability of leaves and stems. Journal of Animal and Veterinary Advances 6: 8-11.

16. Di Paolo, E. and M. Rinaldi. 2008. Yield response of corn to irrigation and nitrogen fertilization in a Mediterranean environment. Field Crops Research 105: 202-210.

17. Emam, Y. 2011. Cereal Production. Shiraz University Press, Shiraz, Iran. (In Farsi).

18. Ertek, A., S. Şensoy, I. Gedik and C. Küçükyumuk. 2006. Irrigation scheduling based on pan evaporation values for cucumber (Cucumis sativus L.) Grown under field conditions. Agricultural Water Management 81: 159-172.

19. Ertek, A. and B. Kara. 2013. Yield and quality of sweet corn under deficit irrigation. Agricultural Water Management 129: 138-144.

20. Farsiani, A., M. E. Ghobadi and S. Jalali-Honarmand. 2011. The effect of water deficit and sowing date on yield components and seed sugar contents of sweet corn (Zea mays L.). African Journal of Agricultural Research 6: 5769-5774.

21. Foryer, C. and G. Noctor. 2000. Oxygen processing in photosynthesis: regulation and signaling. New Phytologist 146: 359-388.

22. Garg, N. and G. Manchanda. 2009. ROS generation in plants: boon or bane? Plant Biosystems 143: 81-96.

23. Hirich, A., A. Rami, K. Laajaj, R. Choukr-Allah, S. E. Jacobsen, L. E. Youssfi and H. E. Omari. 2012. Sweet corn water productivity under several deficits irrigation regimes applied during vegetative growth stage using treated waste water as water irrigation source. World Academy of Science, Engineering and Technology 61: 840-847. 
24. Hu, L., H. Li, H. Pang and J. Fu. 2012. Responses of antioxidant gene, protein and enzymes to salinity stress in two genotypes of perennial ryegrass (Lolium perenne) differing in salt tolerance. Journal of Plant Physiology 169: 146156.

25. Kang, S. Z., P. Shi, Y. H. Pan, Z. S. Liang, X. T. Hu and J. Zhang. 2000. Soil water distribution, uniformity and water use efficiency under alternate furrow irrigation in arid areas. Irrigation Science 19: 181-190.

26. Kazemeini S. A., M. J. Bahrani, H. Pirasteh-Anosheh and S. M. M. Momeni. 2014. Maize growth and yield as affected by wheat residues and irrigation management in a no-tillage system. Archives of Agronomy and Soil Science 60: 1543-1552.

27. Klocke, N. L., R. S. Currie, L. R. Stone and D. A. Bolton. 2010. Planning for deficit irrigation. Journal of Applied Engineering in Agriculture 26: 405-412.

28. Koç, M., C. Barutçular and I. Genç. 2003. Photosynthesis and productivity of old and modern durum wheat in a Mediterranean environment. Crop Science 43: 2089-2098.

29. Lawlor, D. W. 2002. Limitation to photosynthesis in water stressed leaves: stomata vs. metabolism and the role of ATP. Annals of Botany 89: 871-885.

30. Little, T. M. H. and F. Jackson. 1978. Agricultural Experimentation: Design and Analysis. Wiley, New York.

31. Luo, H. H., Y. L. Zhang and W. F. Zhang. 2016. Effects of water stress and re-watering on photosynthesis, root activity, and yield of cotton with drip irrigation under mulch. Photosynthetica 54: 65-73

32. Mittler, R. 2002. Oxidative stress, antioxidants and stress tolerance. Trends in Plant Science 7: 405-410.

33. Niakani, M. and M. Ghorbani. 2007. The effect of drought stress on growth, photosynthetic factors, content of protein, $\mathrm{Na}$ and $\mathrm{K}$ content in two cultivars of soybean. Rostaniha 8: 17-29. (In Farsi).

34. Najafinezhad, H., M. A. Javaheri, M. Gheibi and M. A. Rostami. 2007. Influence of tillage practices on the grain yield of maize and some soil properties in maize-wheat cropping system of Iran. Journal of Agriculture and Social Sciences 25: 52-63.

35. Razzaghi, F. and A. R. Sepaskhah. 2012. Calibration and validation of four common ET0 estimation equations by lysimeter data in a semi-arid environment. Archives of Agronomy and Soil Science 58: 303-319.

36. Villalobos, M. A., D. Bartels and G. Iturriaga. 2004. Stress tolerance and glucose insensitive phenotypes in Arabidopsis over expressing the CpMYB10 transcription factor gene. Plant Physiology 135: 309-324.

37. Xu, P. L., Y. K. Guo, J. G. Bai, L. Shang and X. J. Wang. 2008. Effects of long-term chilling on ultra-structure and antioxidant activity in leaves of two cucumber cultivars under low light. Physiologia Plantarum 132: 467-478.

38. Yordanov, I., T. Tsonev, V. Velikova, K. Georgieva, P. Ivanov, N. Tsenov and T. Petrova. 2001. Changes in $\mathrm{CO}_{2}$ assimilation, transpiration and stomatal resistance of different wheat cultivars experiencing drought under field conditions. Bulgarian Journal of Plant Physiology 27: 20-33. 


\title{
Effect of Incorporation of Wheat Residues to Soil on Physiological Traits and Canned Yield of Sweet Corn under Water Stress
}

\author{
A. Motazedian1, S. A. Kazemeini ${ }^{*}$ and M. J. Bahrani ${ }^{3}$
}

(Received: February 13-2018; Accepted: November 17-2018)

\begin{abstract}
A two-year field experiment (2015-2016) was conducted as a split plot design with four replications at School of Agriculture, Shiraz University, Iran to investigate the influence of water stress (supplying 50, 70, and 100\% of water requirement) and wheat residue rates $(0,25$, and $50 \%)$ incorporated with soil on physiological traits and canned yield of sweet corn (Zea mays L. V. Saccharata). Net photosynthesis rate was decreased under severe stress (supplying 50\% of the water requirement) during vegetative, reproductive and ripening stages of sweet corn by $25.8,15.8$ and $5.5 \%$, respectively, compared to normal irrigation (supplying $100 \%$ of the water requirement). Canned yield decreased significantly with supplying $50 \%$ of water requirement. The lowest values of canned yield $\left(1.1 \mathrm{t} \mathrm{ha}^{-1}\right)$ and harvest index $(23.55 \%)$ were obtained in severe stress and no-residue conditions, indicating approximately 71 and $11 \%$ reductions compared to normal irrigation and no-residue treatments, respectively. In all water stress levels, application of residues led to a yield improvement. In this regard, the highest effect was observed under mild water stress with incorporation of $50 \%$ wheat residues, as it led to two-fold increase in canned yield compared to the increase observed with no-residue treatment. The increased canned yield is attributed to the 30 and $43 \%$ increases in chlorophyll content and net photosynthesis rate, respectively. Overall, it seems that incorporation of wheat residue into soil reduces the effects of water stress through its effects on soil fertility and soil water availability. Therefore, this strategy is suitable for increasing water use efficiency, reducing water stress damage and improving canned yield of sweet corn in areas facing water scarcity.
\end{abstract}

Keywords: Chlorophyll content, Photosynthesis, Water stress

1, 2, 3. MSc Student, Associate Professor and Professor, Respectively, Department of Crop Production and Plant Breeding, School of Agriculture, Shiraz University, Badjgah, Iran.

*: Corresponding Author, Email: akazemeini@shirazu.ac.ir 